\title{
From Symbolism to Realism. Physical and Imaginary Video Game Spaces in Historical Aspects
}

\section{Filip Tołkaczewski}

Kazimierz Wielki University in Bydgoszcz

filiptolkaczewski@ukw.edu.pl | 0RCID: 0000-0002-3310-061X

\begin{abstract}
Physical and imaginary video game spaces have been constantly evolving, starting from dark indefinable space to ultimately become an incredibly realistic world. This paper aims at illustrating how physical and imaginary spaces have evolved. The older games are, the more indefinable and iconic their physical spaces become. In more modern games physical spaces are being more and more developed. It is now possible to move the place of action from the heights of a symbolic universe to a particular land located in a specific timeline, which made it possible to create realistic settings and characters in a life-like manner.
\end{abstract}

Keywords: two-dimensional, three-dimensional, navigational challenges, game space 

Game space needs to be understood as more than a series of polygons or pixelated images experienced on a screen. It is something bounded by technology, processed by the hand, eye, and mind, and embodied in the real and imagined identities of players (Salen, Zimmerman, 2006, p. 68).

Video games are an extremely varied medium. They can be described using many different parameters. One of them is the space - it can be physical, i.e. such that can be observed on a screen or imaginary that exists in the player's mind. Ever since the beginning of their existence, video games have been constantly evolving. This development has been favoured by technological advancements and the desire of game creators to build spaces which would be as accurate representations of the real world as possible. The number of graphical simplifications in games is constantly being reduced. There is no need to resort to using symbols in order to present a game world and compensate for rudimentary graphics. Imaginary spaces are "shrinking" in favour of more complex game environments. There are fewer and fewer "backstage" situations which would have the player visualise what is meant to be presented on the screen. Physical worlds depicted in video games are becoming more detailed and realistic:

it is possible to create any world, any place. The space created for a game does not have to relate to anything, it does not have a beginning [...] nor is it physically restricted (Prajzner, 2010, p. 156). ${ }^{1}$

From a historical perspective it is interesting to examine how the representation of space in games has changed over time due to new possibilities offered by advancements in technology.

\section{The First Video Games}

The history of video games begins in 1947. That year, Thomas T. Goldsmith jr and Estle Ray Mann utilised a CRT monitor and created a simulation

1 „Można wykreować dowolny świat, dowolne miejsce. Przestrzeń, która jest tworzona na potrzeby gry, nie musi się do niczego odnosić, nie posiada żadnego początku [...] ani ograniczenia fizyczne jej nie dotyczą" (Polish quotes are translated by the author). 
of launching missiles. They could be controlled and their speed and direction of flight could be adjusted as well. This invention, however, was not considered a video game (Mańkowski, 2010, p. 11). It was just a preview of what was to come and was not related to computer technology in any way. The invention was called Cathode-Ray Tube Amusement Device, which was a reference to CRT technology of the time (Pitrus, 2012, p. vii).

Spacewar! is thought to be the first video game. It was developed in 1962 and programmed for DEC PDP-1 (Digital Equipment Corporation Programmed Data Processor-1), which was such an expensive computer that it was meant for other purposes. The game was created by a Massachusetts Institute of Technology (MIT) student - Steve Russell. It had the player "take control of a small spaceship and shoot at the incoming enemy. There were only a handful of pixels in the screen but the game was highly complex nevertheless [...]" (Mańkowki, 2010, pp. 13-14). ${ }^{2}$ It was complemented with numerous updates made by Russell's colleagues. "First a starry background was added - it couldn't have been otherwise since it all happened in space" (Mańkowki, 2010, p. 14). ${ }^{3}$ Later, the sun was added, which introduced gravity to the game. Located at the centre of the screen, it affected the missiles' trajectory and pulled the spaceships that got too close. Another addition was the "hyperspace" button which allowed to disappear and reappear at a random point. In May 1962, Russell introduced a scoring system in Spacewar!. It was an innovative move which turned a toy into a point-counting machine that encouraged competitive play.

Nolan Bushnell was fascinated by Russell's achievements. He dreamt of creating the first game in history that would be targeted at a wider audience, however, it was not possible in the 1960s since computers cost a fortune and only a select few scientists and students could use them. In the spring of 1971, Bushnell came up with an idea of how to create a game that could be mass-produced. It became possible owing to rapid technological development and ubiquitous miniaturisation which

2 „[W grze] poruszało się stateczkiem kosmicznym i strzelało do nadlatującego przeciwnika. Na ekranie znajdowało się niewiele pikseli, ale i tak gra była wyjątkowo złożona [...]".

3 „Najpierw pojawiło się gwiaździste tło - nie mogło być inaczej, skoro akcja działa się w kosmosie". 
translated into more affordable prices of the electronics. This way the very first arcade machine came into existence. It was called Computer Space and hosted only a single game.

The game was limited to 99 seconds, when the player controlling a small spaceship was supposed to shoot at two flying saucers. They were also shooting. Whoever scored more hits, won. Having flown outside of the screen you returned on the other side. In case of a collision with a flying saucer, both sides scored a hit. The player could control direction, acceleration, shooting and hyperspace with keys [...] (Mańkowski, 2010, p. 17). ${ }^{4}$

The device was placed in many American bars, supermarkets and bowling alleys. Its creator is thought to be the father of video games.

The next phase in the history of video game development was the rise of home consoles. Games could be enjoyed in the privacy of one's home. Ralph Baer's creation - the Brown Box - was a prototype of the first console - Odyssey. It was released by Magnavox in March 1972. It constituted the first programmable device designed with video games in mind. At the moment of its release its library consisted of 12 games. These were simple games such as football, volleyball, tennis, and others which came with the console and were inseparable components of the bundle. The machine did not generate sound. In his internet series AVGN (Angry Video Game Nerd), James Rolfe points out that those games are so primitive that today it is even difficult to classify them as video games. Probably this was the reason why the console was bundled with numerous accessories, such as dice, boards, cards, and colourful screen overlays. Games were stored on carts which looked like primitive game cartridges. They were not labelled. Instead, numbers were used. They were programmed only slightly differently and differed merely in the accessories required to play them, since the console could only display three glowing dots (Rolfe, 2009, 1:58-9:31).

As the time went by "the idea of putting all the exciting games in one magic box started to give way to the idea of creating a console for which

4 „Gra [owa] ograniczała się do 99 sekund, podczas których, kierując niewielkim stateczkiem, trzeba było strzelać do dwóch latających spodków. One również strzelały. Ten, kto zaliczył więcej trafień, wygrywał. Wyleciawszy poza ekran, powracało się po jego przeciwległej stronie. W przypadku kolizji z latającym spodkiem trafienie było zaliczane każdej ze stron. Gracz miał do dyspozycji klawisze obrotu w obie strony, przyspieszenia, strzału oraz nadprzestrzeni [...]". 
games could be developed by independent teams and sold separately at prices determined by the law of demand and supply" (Mańkowski, 2010, p. 22). ${ }^{5}$ Later on, this approach allowed to adjust the game library to the player's individual needs and preferences. On 27th June 1972, Nolan Bushnell and Ted Dabney set up a new computer company in California which they called Atari. The company's first success was the release of the Pong arcade $\left(29^{\text {th }}\right.$ November 1972). It was a tremendous step forward when compared to the Magnavox Odyssey. Among the most important changes one could find the introduction of sound, scoring system, as well as improved animation of the ball. In 1976, the Fairchild Semiconductor created a new console - Fairchild Channel F. It began the second generation of video game consoles. "It was the first machine in history to ever use [...] cartridges, that is games sold separately and inserted into the console's game slot" (Mańkowski, 2010, p. 32). ${ }^{6}$ This way games stopped being an integral component of the device. "It allowed for the production of an unlimited number of games, since they were no longer part of the hardware but could be added as pieces of memory" (Mańkowski, 2010, p. 32). ${ }^{7}$ Atari answered with the release of the Atari VCS (Video Computer System) in the Autumn of 1977. In reality, it was an 8-bit computer designed for games on cartridges. Since 1982 it has also been known as the Atari 2600.

\section{The symbolic nature of space in the first video games}

Atari VCS could boast a vast game library (Mańkowski, 2010, p. 32). Many versions of the greatest arcade hits of the time were developed for the platform. This let players enjoy games at home without having to constantly insert coins into an arcade cabinet. The system sold incredibly well in America and on other continents as well. Games had become more popular

5 „Pomysł umieszczenia w jednym magicznym pudełku wszystkich najciekawszych gier ustępował idei stworzenia konsoli, do której gry byłyby produkowane przez niezależne zespoły, sprzedawane osobno po cenach ustalonych przez prawa popytu i podaży”.

6 „Jako pierwsza maszyna w historii korzystała [...] z cartridgéów, czyli dokupowanych osobno gier, wkładanych do odpowiedniego gniazdka w konsoli".

7 „Umożliwiło to produkowanie nieskończonej ilości gier na tę konsolę, gdyż nie stanowiły one części hardware’u, lecz były dodawane do nich jako kawałki pamięci”. 
and accessible. However, they were still extremely limited by the technological capabilities of the 8-bit console. Their space was very narrow. They lacked vast three-dimensional areas that we know from modern games. There would only be two-dimensional graphics that usually occupied the space of a single screen. Action took place in the indefinable heights of outer space. Creating such places did not require a lot of computational power, but instead it created a futuristic aura of the whole gameplay.

The issue of space in video games can be viewed from a range of different perspectives and in the context of various research problems. The virtual environment may be treated as a background of the events or one of the sources of information about the game world, it may also be regarded as an enemy that has to be defeated, finally it may be a visual attraction that encourages the participation in the game. In all of the above cases the key category seems to be the experience of traversing the virtual space (Chojnacki, 2014, p. 59). ${ }^{8}$

Anna Nacher also stresses that "the category of space is crucial in determining how video games tell stories and create their worlds" (2012, p. 115).9 The symbolic nature of space in the first video games started to change at the turn of the 1970s and 1980s. It was replaced with more illusory yet still highly symbolic space. Space Invaders (1978), Asteroids (1979) or Yars' Revenge (1982) are examples of such changes. The first two titles were released for the arcades and only later ported to the Atari 2600, whereas Yars' Revenge was available exclusively on the home console. A common feature of those games is the fact that their space was limited to just one screen where all the action took place. Outer space was the setting for many games. Simple symbols appeared on the screen and, depending on the game, they represented objects like alien spaceships, asteroids or insects.

The sense of graphic attractiveness of the game world was intensified by an increase in the number of screens that a game consisted of. It may

8 „Zagadnienie przestrzeni w grach komputerowych może być rozpatrywane z szeregu różnych perspektyw i w kontekście różnych problemów badawczych. Wirtualne środowisko można potraktować jako tło dla wydarzeń opisywanych przez narrację lub jedno ze źródeł informacji o świecie przedstawionym, uznać za przeciwnika, którego trzeba pokonać, w końcu może ono stanowić atrakcję wizualną zachęcającą do uczestniczenia w rozgrywce. We wszystkich tych przypadkach kluczową kategorią wydaje się być doświadczenie jakim jest przemierzanie wirtualnej przestrzeni".

9 „Kategoria przestrzeni ma zasadnicze znaczenie dla sposobu, w jaki gry wideo opowiadają i tworzą swoje światy przedstawione". 
be exemplified with such games as Adventure (1979) and Gravitar (1982). The size of space in those two titles differs significantly from that of the games mentioned earlier. As the name implies, Adventure is an adventure game with a large number of symbols that compensate for rudimentary graphics. The player's goal is to find the Enchanted Chalice that an evil magician has stolen and hidden in the kingdom and return it to the Golden Castle. The game's world is comparatively simple. Whenever the player reaches the edge of the screen they automatically appear in the next one. It is not followed by any animation. The only illusion of moving is created by a change in colours and shapes of the on-screen level. It creates clear boundaries between the particular screens. This technique is known as flip-screen and to a varying degree it was used in numerous games of the second and third generation.

Unlike the fantastical kingdom of Adventure, the action of Gravitar is set in outer space. All it takes is just a glance to determine that Gravitar is a spiritual successor of Spacewar!. The first screen is a representation of a planetary system with a sun in the middle. In contrast to Spacewar! it is full of additional objects and celestial bodies. They all have their own gravitational fields and may pull the player's blue ship. Every now and then a flying saucer flies through the screen and tries to shoot the player's craft down. A collision with the saucer or the star in the middle of this system is equivalent to losing the game. However, on moving closer to any other object the player is taken to a different screen. The screen is changed and so is the perspective. The top-down perspective is replaced with the side viewpoint, present in all stages but the main one. The goal of the game is to visit all the planets and accomplish certain missions. Once this task has been completed, the player is transported to another universe that is governed by different laws of physics, for example instead of being attractive gravity is repulsive.

\section{Virtual world, storylines and well-defined characters}

With the passage of time, technology improved and game worlds constantly grew bigger and bigger. The year 1980 represented a breakthrough, as that was the time when the Defender was released for the arcades. 
A year later it was ported over to the Atari 2600 (VCS). By that time the ingame animation had become so smooth that all the boundaries between screens simply ceased to exist and thus a new type of game was born. It was referred to as the side-scroller. This kind of games was characterised by a total lack of division between individual, independent screens. Instead, travelling through space is represented by a smooth background movement which can be either horizontal or vertical. Another revolution that Defender introduced was the creation of a virtual (i.e. illusory, imaginary) world where events could also happen outside of the visible screen. This was a completely novel idea, never seen before in any game at the time. Up until that moment, "action was set in one screen. The screen was the whole world. Even if it was possible to move in some bigger space, everything that the player was concerned with was visible on the screen" (Mańkowski, 2010, p. 65)..$^{10}$ The objective of the game was to protect people from aliens who were attacking and trying to abduct them. The player could ascertain what was happening on the screen by means of a radar. It was the embodiment of the concept described by Magdalena Kamińska: "The essence of virtuality of a given object is the fact that it does not exist physically, yet it functions in the reality accessible to human senses" (2007, p. 98). ${ }^{11}$

The rise of the third generation of consoles, in 1983, on the Japanese market marked another phase in the history of video game development. It was linked to the birth of the Nintendo Entertainment System (NES), which was a technological powerhouse of the era. Thanks to its immense computational power side-scrollers became a standard. Nonetheless there were still some exceptions. One of them was the game Donkey Kong. In the beginning it was available exclusively for the arcades but it came a long way across many different platforms to eventually make its way to the NES in 1983 in Japan ${ }^{12}$ and 1986 in America and

10 „Akcja toczyła się na jednym ekranie. Ekran był całym światem. Nawet jeśli można się było przemieszczać w jakiejś większej przestrzeni, wszystko, co dotyczyło gracza, znajdowało się zawsze na ekranie".

11 „Istotą wirtualności danego obiektu jest to, iż nie istnieje on w sposób fizyczny, a jednak funkcjonuje w rzeczywistości zmysłowo dostępnej człowiekowi”.

12 In Japan the NES looked different. It was known as the Famicom and was launched two years prior to its American counterpart. 
Europe. It was the very first game to have a storyline and well-defined characters. According to Piotr Mańkowski "critics consider it to be the first game whose development started from creating the plot and the characters and only later moving to the programming itself" (2010, p. 73). ${ }^{13}$ From that moment onwards many games featured well-defined characters and a definite place of action. Frequently it was something else than outer space. It was possible due to greater computing power of the third-gen consoles. Games could be characterised as having multicolour backgrounds, which intensified the sense of realism and expanded the game space.

The most notable example is Super Mario Bros., from 1985, released for the Nintendo Entertainment System (NES). It was a side-scrolling platform game. The player moved right, which was accompanied by a smooth background animation. The game did not allow for moving back. What disappeared on the left was gone forever, whereas new, so far unseen space was constantly being uncovered on the right. The game consisted of 32 stages, each of them being much larger than a single shot.

\section{Navigational challenges - the golden age 2D games}

Super Mario Bros. was a game posing "navigational challenges" (Dovey, Kennedy 2011, p. 121). "One of the fundamental challenges that the player has to face is the necessity to learn how to function in a virtual environment by using a steerable character" (Chojnacki, 2014, p. 59). ${ }^{14}$ A game involves moving an avatar in a two-dimensional space. All the on-screen objects are obstacles that force the player to behave in a particular way. Henry Jenkins calls them navigational challenges. According to Jon Dovey and Helen W. Kennedy, mastering the game space and overcoming obstacles that it presents brings joy in itself (2011, p. 123). The space

13 „[...] jest uznawana przez krytyków za pierwszą grę wideo, której powstanie rozpoczęło się od szczegółowego wymyślenia fabuły oraz bohatera, a dopiero potem przystąpiono do jej zaprogramowania".

14 „Jednym z podstawowych zadań stawianych przed graczem jest konieczność odnalezienia się w wirtualnym środowisku przy wykorzystaniu sterowalnej postaci”. 
that the player explores is called "navigational space" by Lev Manovich (2001, p. 371).

Three years later, in 1988, the game Contra was developed for the NES. Just like Mario, it was a side-scrolling title, yet it was much more advanced in terms of graphics and gameplay mechanics. This time running on the screen was a character that could jump, lie down and shoot in eight different directions. The game was divided into eight diverse levels and each of them was very detailed. Similarly to Super Mario Bros., the player had no choice but to go to the right and could not return to the starting point. However, contrary to the adventures of the Italian plumber, Contra also included vertically-scrolling levels as well as pseudo-3D stages where the character was seen from behind. The game's ultimate goal was to defeat a terrorist organisation Red Falcon and to reach the very heart of an alien invasion to confront it.

2D games evolved quickly. Developments in technology which resulted in the emergence of the fourth-gen consoles led to significant improvements rendering games much more complex. From then on games were longer, offered more levels and allowed to save progress of the player. Thus titles offering a save feature had enormous spaces that could be explored for hours on end. Consequently, the time needed to complete them was significantly extended. This period is considered by many the golden age of $2 \mathrm{D}$ games. However, it was all to change at the dawn of the year 1993 when a new generation of consoles appeared and the 3D era began. Even though $3 D$ Monster Maze is thought to be the first $3 \mathrm{D}$ game, it was the consoles like PlayStation 1 (1995) and Nintendo 64 (1996) that contributed to the popularisation of true $3 \mathrm{D}$ gaming and made it a standard.

\section{The beginning of 3D games}

Before we delve deeper into the description of $3 \mathrm{D}$ games, let us take a closer look at some psedo-3D games. The first of them is the abovementioned 3D Monster Maze. The player was supposed to wander through narrow corridors of a labyrinth while trying to escape from a T-Rex. Wolfenstein and Doom may serve as further examples. In both of them, the player roamed around $3 \mathrm{D}$ corridors viewing the area from the first 
person perspective. The sheer scale of the virtual space makes it easy to get disoriented and lost. Gameplay-wise both titles are very similar, yet it is the setting that sets them apart. Wolfenstein sends hordes of Nazis and vicious dogs against the player. In contrast to Wolfenstein, Doom tells a story of a space marine who was made to confront a horde of demons from hell. Action is set in the future in a space station on Mars. Despite such dissimilar scenery, both games have quite a lot in common, especially in terms of 3D space exploration and fighting mechanics. Yet neither of them can be regarded as fully 3D. The only three-dimensional thing are the environments, while characters and numerous objects are in fact two-dimensional. They are only shown from different angles, thus making an illusion of being 3D.

No technological barriers prevented the creation of interesting characters. But it was not until the gos that game designers were finally capable of creating believable environments. That is the ones that would at least slightly resemble the world that we live in. At the beginning of the 9os, it started to rapidly change (Mańkowski, 2010, p. 185). ${ }^{15}$

The introduction of texture mapping, CD-ROM drive, as well as artificial intelligence allowed for creating more detailed virtual worlds, more closely resembling the real one.

\subsection{Creating virtual worlds that resemble the real one}

The following step was the transition of the Mario series from $2 \mathrm{D}$ to $3 \mathrm{D}$, which became possible owing to the immense power of the N64 - a fifthgen console. In Super Mario 64 the famous plumber travelled through vast spaces, completed some challenges and fought a number of enemies on his way to the evil Bowser who had kidnapped princess Peach. It was such a drastic change within the technological domain that many found it overwhelming. The game world seemed huge in comparison to the previous instalments in the series. This title contributed to the setting

15 „Tworzeniu ciekawych postaci nie przeszkadzały żadne bariery techniczne. Natomiast aż do początku lat 90. projektanci gier mieli problem z uzyskaniem wiarygodnych środowisk. To znaczy takich, które choćby w małym stopniu przypominałyby świat, w którym żyjemy. Na początku lat 90. zaczęło się to gwałtownie zmieniać". 
of new standards in the world $3 \mathrm{D}$ platform games. It was the first one to allow independent camera and character movements.

The first 3D games came with static environments. With time, more and more moving elements were added, independent from the player and not related to the plot. It started to rain, the grass was waving, and [...] [when a character was wading] ripples appeared on the water's surface (Mańkowski, 2010, p. 222). ${ }^{16}$

The 3D Realms' advertising slogan "Reality is our game" adequately described that period. It was a reference to more and more sophisticated ways of mirroring the physical world (2010, p. 222).

The growing popularity of the third dimension and the launch of modern GPUs pushed the progress even further, thus making virtual worlds even more similar to the real one than before. "[They] were shrouded in fog, half-lights were added and even darkness [...]" (2010, p. 265). ${ }^{17}$

Following generations of consoles kept being launched onto the market. At present we can witness the transition from the seventh to the eighth generation. The current trends are remastering games from the past, creating many sandbox games, i.e. open world games with nonlinear plot, and blurring the line between games and films.

The first of those phenomena is by no means a novelty. Arguably one of the earliest remasters is the Super Mario Bros. ported to the Super Nintendo Entertainment System (SNES), although it was not until fairly recently that this practice became common.

Another trend - an increase in the number of sandbox games is closely related to the tremendous computing power offered by modern computers and consoles. There are countless titles that provide almost unlimited freedom of exploration and vast space, albeit describing them all would be an impossible task.

Whenever the term "sandbox" is used many people think of the Rockstar's GTA series. Grand Theft Auto can boast five instalments in the main

16 „Pierwsze gry 3D miały statyczne środowiska. Z czasem zaczęło się w nich pojawiać coraz więcej elementów ruchomych, niezależnych od gracza i niezwiązanych z fabułą. $\mathrm{Z}$ nieba zaczął padać deszcz, falowała trawa, a [...] [gdy postać chodziła] po wodzie, pojawiały się w niej koła".

17 „Zaczęła [je] przenikać mgła, pojawiły się półcienie, a nawet zmrok [...]”. 
series. Each one gradually increased the number of possibilities for the player and offered more and more space to explore. The player could focus on the main plot-related quests or just explore the city in search of attractions while the game offered more than enough of them.

\subsection{Space as an adversary that has to be defeated}

Another important series, which can also be considered a part of the sandbox genre, is the Souls series that originated in the seventh generation of consoles. The first game in the series - Demon's Souls - was released in 2009 exclusively for the PlayStation 3. Later the series grew and expanded into other platforms, also including PCs. First, Dark Souls became available for the $\mathrm{PS}_{3}, \mathrm{X}_{3} 60$ and $\mathrm{PC}$. Then, its sequels, along with Bloodborne, followed. All of these games have much in common. What is typical of all them is an enormous world that the player can explore as they see fit, even out of the intended order, and an insane difficulty level. For this reason, as Marcin Chojnacki claimed in the quote mentioned above, it can be said that the space itself is an adversary that has to be defeated. Driven by curiosity, the player moves through the three-dimensional space. Not every path is equally easy, for there are groups of mighty foes lurking around every corner. Corridors may be full of traps. These games constantly keep the players on their toes, since even an innocent looking treasure chest may be a deadly enemy.

\subsection{Blurring the line between films and games}

Blurring the line between films and games is one of the most recent trends. A good example of this may be such games as Heavy Rain, Metal Gear Solid, and The Last of Us. Heavy Rain is more of a cinematic experience than an actual game. Only from time to time can the player explore it relatively freely. The whole gameplay is filled with quick time event sequences where the player is supposed to press the right button combination or else something bad will happen. In a lull the player only has to watch cutscenes that are to explain the convoluted plot and help the player solve a criminal case.

Metal Gear Solid is a series of Hideo Kojima's games that deal with conspiracy theories concerned with world domination. One of the main characters is the agent Snake. The latest instalments offer large space, but the gameplay can be described as rather linear. What these games are 
famous for are extremely long cinematics. Probably the longest one can be found in the fourth game - Metal Gear Solid 4: Guns of the Patriots. It lasts approximately an hour and a half which is more or less as long as big budget films - and it is but an addition that is only supposed to move the complicated story forward.

In the game The Last of Us, two characters - Joel and Ellie, travel through the ruined territory of the USA in search of a cure for the virus which almost led humanity to extinction. The player sees the world from behind Joel's back. Despite offering rather large spaces, the game is quite linear and the player only moves in one, already predetermined direction. On the way, the player faces many infected people that have been horribly disfigured and turned into mindless monstrosities by the virus. Apart from them, Joel and Ellie have to fight soldiers and gang members that kill and loot unwary travellers. The aspect of survival is highly emphasised in the game. In order to survive, the player has to manage their resources well, otherwise they will become an easy prey unlikely to escape death. The story is far simpler than that of the two previous games but it is the film-like aspect that makes it so engaging rendering the gameplay more captivating, realistic, and emotion-inducing.

A fun fact is that the tendency to make video games more film-like is not anything new. It could be observed many years ago, which is exemplified by a series of strategy games Command $\mathcal{E}$ Conquer: Red Alert that dates back to 1996. All the FMVs featured real actors. However, due to large discrepancies between cutscenes and the in-game graphics, a truly filmlike experience could not be delivered. Now, since modern games run exclusively on an in-game engine and all the discrepancies between cinematics and gameplay have disappeared, it is far more likely for the player to feel like they were watching a more or less realistically looking film. The emergence of such games has made game worlds significantly more realistic. Some of the games available today depict such realistic or plausible worlds and events that only the graphics or a limited degree of exploration distinguish them from films.

\subsection{Video games as an allegorical representation of space}

Espen Aarseth claims that space in video games is not a derivative of the cinema but a phenomenon that came into being independently. 
"Computer games are allegories of space: they pretend to portray space in ever more realistic ways but rely on their deviation from reality in order to make the illusion playable" (Aarseth, 2007, p. 47). Hence it can be stated that the in-game reality is slightly altered and simplified. This makes the game slightly simpler and reduces its length. For example, a long journey takes only a moment instead of hours or even days. A character's equipment is another thing worth taking into account. In some games the player can carry up to a dozen weapons which they can switch between at any moment. All it takes is a click of a button and instead of a rifle the character is now equipped with a sword. Such situations make the game simpler but at the same time more distant from the real world.

All in all, it can be stated that at the beginning games had a simple structure. Usually only one programmer was responsible for their development. Their task involved creating an interesting world and original gameplay mechanics while taking the technological limitations into account. More often than not such a process did not take too long nor did it require considerable financial outlays. Games were highly symbolic, which stimulated the player's imagination. Players often wondered what happens to an on-screen character at some points of the game. Pac-Man serves as a good example. The title character could go through a tunnel to the opposite side of the screen. In Katie Salen and Eric Zimmerman's book we can find a quote from Daniel Weiss who points out that if we assume that Pac-Man travels through the tunnel at a constant speed then it must have covered the distance of approximately six dots by the time it appeared on the other side. The invisible space outside of the screen was very mysterious. No one knew what was happening to Pac-Man in the tunnel. For this reason Weiss defines such space as real, yet empirically inaccessible. On the other hand, Michael Nitsche uses the term impossible spaces (Salen, Zimmerman 2006, p. 65; Nitsche, 2008, p. 118). Such aspects of video games allowed for a greater freedom of interpretation.

Modern games require a large budget that is frequently greater than that of the latest films. They are longer, more complicated and more accurately reflect reality. There is less room for interpretation of the game world, because everything is already visible. Very often there is no need to imagine what something looks like in the game world, since it already has its own graphical representation. Video games have come a long 
way and changed significantly. They started from three dots glowing on the screen and now have reached the point where the line between the real/physical world and the virtual cyberspace is becoming more and more blurry. If compared to their ancestors, modern games provide much more visual stimulation. This is clearly illustrated by the departure from iconic game worlds towards much more realistic ones. Games are becoming less symbolic and turning into a new medium - the interactive film. We are more and more likely to give up on playing in favour of acting or watching, while at the same time being able to control the on-screen action and interfering in the story.

\section{References}

Aarseth, E. (2007). Allegories of Space. In: F. von Borries, S. P. Walz, M. Böttger (Eds.), Space Time Play Computer Games, Architecture and Urbanis: The Next Level (pp 44-56). Basel: Birkhäuser Verlag AG.

Chojnacki, M. (2014). "Flâneur" w piaskownicy - o doświadczeniu nawigowalnej przestrzeni w grach komputerowych. Replay. The Polish Journal of Game Studies, 1(1), 59-68. Online: <http://dspace.uni.lodz. pl:8080/xmlui/bitstream/handle/11089/8873/07\%20Chojnacki.pdf? sequence $=1 \&$ isAllowed $=y>$.

Dovey, J., Kennedy, H. W. (2011). Kultura gier komputerowych (transl. by T.Macios, A. Oksiuta). Kraków: Wydawnictwo Uniwersytetu Jagiellońskiego.

Kamińska, M. (2007). Rzeczywistość wirtualna jako „ponowne zaczarowanie świata". Pytanie o status poznawczy koncepcji. Poznań: Bogucki Wydawnictwo Naukowe.

Manovich, L. (2006). Język nowych mediów (transl. by P. Cypryański). Warszawa: Wydawnictwa Akademickie i Profesjonalne.

Mańkowski, P. (2010). Cyfrowe marzenia. Historia gier komputerowych i wideo. Warszawa: Wydawnictwo Trio - Collegium Civitas.

Nacher, A. (2012). Między grą a codziennością - mobilne gry w przestrzeni hybrydowej. In: A. Pitrus (Ed.). Olbrzym w cieniu. Gry wideo w kulturze audiowizualnej (pp 115-134). Kraków: Wydawnictwo Uniwersytetu Jagiellońskiego. 
Nitsche, M. (2008). Video Game Spaces: Image, Play, and Structure in 3D Game Worlds. Cambridge: MIT Press.

Pitrus, A. (2012). Miejsca zabawy. O przedstawieniach przestrzeni w grach wideo. W: A. Pitrus (Ed.). Olbrzym w cieniu. Gry wideo w kulturze audiowizualnej (pp 19-27). Kraków: Wydawnictwo Uniwersytetu Jagiellońskiego.

Prajzner, K. (2010). Wirtualne spacery. Struktury przestrzenne w grach komputerowych. Kultura Wspótczesna, 18(3), pp 151-163.

Rolfe James (2009). Odyssey - Angry Video Game Nerd - Episode 68. Online: <http://www.youtube.com/watch?v=kDAKxjG7VaI>.

Salen, K., Zimmerman, E. (2006). Game Spaces. In: K. Salen, E. Zimmerman (Eds.). The Game Design Reader (pp 65-69). Cambridge: MIT Press.

All the Internet sources were consulted on the $30^{\text {th }}$ August 2015.

\section{Ludography}

Atari (1979). Adventure [Atari 2600]. Atari, USA.

Atari (1981). Asteroids [Atari 2600]. Atari, USA.

Atari (1982). Yars' Revenge [Atari 2600]. Atari, USA.

Atari (1982). Gravitar [Atari 2600]. Atari, USA.

DMA Design (1997). Grand Theft Auto [PC]. BMG Interactive, UK.

DMA Design (2000). Grand Theft Auto 2 [PC]. Rockstar Games, USA.

DMA Design (2001). Grand Theft Auto III [PC]. Rockstar Games, USA.

EA Los Angeles (2008). Command \& Conquer: Red Alert 3 [PC]. Electronic Arts, USA. Evans Malcolm (1982). 3D Monster Maze [ZX81]. J. K. Greye Software, UK. FromSoftware (2009). Demon's Souls [PS3]. Namco Bandai Games, Japan. FromSoftware (2011). Dark Souls [X360]. Namco Bandai Games, Japan. FromSoftware (2014). Dark Souls II [PC]. Namco Bandai Games, Japan. FromSoftware (2015). Bloodborne [PS4]. Sony Computer Entertainment, Japan. id Software (1992). Wolfenstein3D [PC]. Apogee Software, USA.

id Software (1993). Doom [PC]. GT Interactive, USA.

Kojima Productions (2008). Metal Gear Solid 4: Guns of the Patriots [PS3]. Konami, Japan.

Kojima Productions (2015). Metal Gear Solid V: The Phantom Pain [PC]. Konami Digital Entertainment, Japan.

Konami (1988). Contra [NES]. Konami, Japan. 
Konami Computer Entertainment Japan (1998). Metal Gear Solid [PS1], Konami, Japan.

Konami Computer Entertainment Japan (2001). Metal Gear Solid 2: Sons of Liberty [PS2]. Konami, Japan.

Konami Computer Entertainment Japan (2004). Metal Gear Solid 3: Snake Eater [PS2]. Konami, Japan.

Namco (1980). Pac-Man [NES]. Midway Games, USA.

Naughty Dog (2013). The Last of Us [PS3]. Sony Computer Entertainment, USA.

Nintendo EAD (1993). Super Mario All-Stars [SNES]. Nintendo, Japan.

Nintendo EAD (1996). Super Mario 64 [N64]. Nintendo, Japan.

Nintendo Research \& Development 2 (1986). Donkey Kong [NES]. Nintendo, Japan.

Nintendo Creative Department (1985). Super Mario Bros. [NES]. Nintendo, Japan.

Quantic Dream (2010). Heavy Rain [PS3]. Sony ComputerEntertainment, USA. Rockstar North (2008). Grand Theft Auto IV [X360]. Rockstar Games, USA. Rockstar North (2013). Grand Theft Auto V [X360]. Rockstar Games, USA. Russell Steve (1962). Spacewar! [PDP-1]. Russell Steve, USA.

Syzygy Engineering (1971). Computer Space [Arcade]. NuttingAssociates, USA. Taito (1980). Space Invaders [Atari 2600]. Midway, USA.

WestwoodStudios (2000).Command\& Conquer:RedAlert2 [PC].EA Games, USA. Westwood Studios (1996). Command \& Conquer: Red Alert [PC]. Virgin Interactive, USA.

Williams Electronics (1981). Defender [Atari 2600]. Williams Electronics, USA.

Filip Tołkaczewski, MA - an applied linguist, Ph.D. student of linguistics and lecturer at Kazimierz Wielki University in Bydgoszcz, Poland

\section{Od symbolizmu do realizmu. Fizyczna i wyobrażeniowa przestrzeń gier w ujęciu historycznym}

Abstrakt: Przestrzeń fizyczna i wyobrażeniowa gier wideo nieustannie ewoluuje, poczynając od niedookreślonego, ciemnego świata kosmosu aż po świat niezwykle realistyczny. Celem artykułu jest ukazanie przeobrażeń, jakie zachodziły pomiędzy tymi przestrzeniami. Im starsze są gry wideo, w tym większym stopniu, przestrzeń fizyczna jest nieopisana i ikoniczna, im nowsze zaś, 
tym bardziej rozbudowana. Możliwe stało się przeniesienie akcji z wyżyn symbolicznego kosmosu do krainy umiejscowionej na osi czasu oraz bardziej wierne odwzorowanie rzeczywistości otaczającej bohatera,jaki samego bohatera.

Stowa kluczowe: dwuwymiarowość, trójwymiarowość, wyzwania nawigacyjne, przestrzeń gry 